\title{
Comparative Energetic, Exergetic, Environmental and Enviroeconomic Analysis of Vapour Compression Refrigeration Systems Using R515B as Substitute for R134a
}

\author{
Ragıp Yıldırım*, Arzu Şencan Şahin², Erkan Dikmen² \\ ${ }^{1}$ Deparment of Electrical and Energy, Bucak Emin Gülmez Vocational School of Technical Sciences, Burdur Mehmet \\ Akif Ersoy University, 15300, Burdur, Turkey \\ ${ }^{2}$ Department of Mechanical Engineering, Faculty of Technology, Isparta University of Applied Sciences, 32200, Isparta, \\ Turkey \\ E-mail: ${ }^{*}$ ryildirim@mehmetakif.edu.tr
}

Received 18 Oct 2021, Revised 13 December 2021, Accepted 24 January 2022

\begin{abstract}
In this study, hydrofluoroolefin R515B was used rather than hydrofluorocarbon R134a to perform energetic, exergetic, environmental and enviroeconomic analyses on vapor-compression refrigeration systems with internal heat exchangers. The exergy efficiency, exergy destruction, and coefficient of performance for cooling mode (COP) were studied. EES (Engineering Equation Solver) program was employed for thermodynamic analysis. The impact on the COP, exergy destruction, and exergy efficiency of the system was investigated at various evaporator and condenser temperatures. Performance analysis shows that the COP of R515B refrigerant is like that of R134a. It has been found that the exergetic efficiency of R515B was slightly lower (about 1.40\%) than that of R134a. It has also been found that at higher evaporation temperatures, the total exergy destruction increases. The most important exergy destruction occurs in the compressor. The environmental and enviroeconomic indexes of R515B refrigerant were like those of R134a. The results demonstrated that R515B may be a good alternative to R134a in the vapourcompression refrigeration systems with internal heat exchangers.
\end{abstract}

Keywords: Vapor compression refrigeration; energy; exergy, global warming; new generation refrigerants.

\section{Introduction}

Concrete alternatives to the burning of fossil fuels have yet to be found. In the meantime, more and more greenhouse gases are being emitted daily for generating electricity and heat (industries, the transportation sector etc.). An increase in the atmospheric concentrations of greenhouse gases produces several undesirable environmental problems. People widely use heating, ventilation, air conditioning, and cooling systems (HVAC$\mathrm{R})$ to provide their needs and comfort in their daily lives. The energy consumed by HVAC-R is substantial. HVAC-R systems negatively affect the environment due to their energy consumption and refrigerant leaks. The refrigerant's ozone depletion potential (ODP) and global warming potential (GWP) used in HVAC-R are commonly used to evaluate the effects of refrigerants on the environment.

R134a of the HFCs group is widely used in vaporcompression systems owing to its perfect thermodynamic properties. Nevertheless, the GWP rate of R134a is very high. Therefore, R134a refrigerants are listed as controlled greenhouse gases by the Kyoto protocol (1997). With the Montreal protocol - Kigali amendment (2016), it was decided to phase out the use of R134a refrigerant [1] Developed as an alternative to HFCs, hydrofluoroolefins (HFOs), also known as fourth-generation refrigerants, have not been extensively studied in a variety of applications. Manufacturers of refrigerants have been trying to develop HFOs, a new generation of refrigerants that has a lower
GWP and can be used as an alternative to existing HFCs. It is therefore important to find alternative refrigerants with a lower GWP that can be used instead of R134a.

The choice of refrigerant for vapor-compression refrigeration systems depends on some criteria such as thermodynamic properties, safety (flammability and toxicity), cheapness, availability, zero ODP, and lower global potential. The current alternative refrigerants fall in two categories: (I) pure refrigerants and (II) refrigerant mixtures. In general, mixed refrigerants are preferred as alternative refrigerants due to theirs lower GWP rates. In the selection of refrigerants, good thermophysical properties, its safety (toxicity and flammability), economy, environmental protection, and cycle performance parameters must be sought [2], [3].

Possible working fluid alternatives are given in Table 1. GWP value and flammability of R1234yf and R1234ze(E) are very low (A2L by ASHRAE). The non-flammable mixtures of R450A and R513A show promising results, but their GWP values are both about 550. Although the GWP rates of $\mathrm{R} 450 \mathrm{~A}$ and $\mathrm{R} 513 \mathrm{~A}$ are quite low compared to R134a, these rates are still high. The R515B refrigerant with low GWP (299) is a mixture of R1234ze(E)/R-227ea (91.1/8.9). It is also included in the non-flammable group by the ASHRAE classification (A1). The use of R515B instead of R134a in vapor compression systems hasn't been extensively studied yet. Therefore, R515B refrigerant is used as an alternative to $\mathrm{R} 134 \mathrm{a}$ in this study. 
Table 1. Main characteristics of some refrigerants that may be alternatives to R134a [4], [5]

\begin{tabular}{lccccccc}
\hline Refrigerants & $\begin{array}{c}\text { Mass of } \\
\text { molar } \\
(\mathrm{kg} / \mathrm{kmol})\end{array}$ & $\begin{array}{c}\text { Boiling } \\
\text { Point } \\
\left({ }^{\circ} \mathrm{C}\right)\end{array}$ & $\begin{array}{c}\text { Critical } \\
\text { Point } \\
\left({ }^{\circ} \mathrm{C}\right)\end{array}$ & $\begin{array}{c}\text { Critical } \\
\text { Pressure } \\
(\mathrm{MPa})\end{array}$ & $\begin{array}{c}\text { Security } \\
\text { Group }\end{array}$ & ODP & GWP \\
\hline R134a & 102 & -26.10 & 101.06 & 4.06 & A1 & 0 & 1300 \\
R1234yf & 114 & -29.49 & 94.70 & 3.38 & A2L & 0 & $<1$ \\
R1234ze(E) & 114 & -18.97 & 109.36 & 3.64 & A2L & 0 & $<1$ \\
R516A & 102 & -29.40 & 96.80 & 3.62 & A2L & 0 & 131 \\
R513A & 108 & -28.30 & 97.70 & 3.70 & A1 & 0 & 573 \\
R515B & 117 & -18.89 & 108.70 & 3.56 & A1 & 0 & 299 \\
R450A & 108 & -23.35 & 104.47 & 3.82 & A1 & 0 & 547 \\
* Security group: & & & & & & \\
(a) A: Low Toxicity, B: High Toxicity; & & & & & \\
(b) 1: Not flammable, 2: low flammability, 3: highly flammable. & & & & \\
\hline
\end{tabular}

Over the years a pretty good number of articles have been published in the literature on cooling systems that use refrigerants as substitutes for R134a. Ahmed et al. (2012) [6] studied the energetic and exergetic analyses of household refrigerators usage of natural isobutane and butane. They compared the performance of mixture of butane and isobutane with that of R134a in a refrigeration the system. They found that the COP of the mixture was equal to that of R134a. They also compared exergy efficiency of isobutane and R134a, and they stated that butane has higher exergy efficiency. Wantha (2019) [7] investigated the characteristics of the heat transfer of inner tube heat exchanger theoretically and experimentally using R1234yf and R134a refrigerants. He found that the coefficient of heat transfer of R134a is higher than that of R1234yf. The effectiveness of the interior heat exchanger on the exergetic efficiency was also investigated in his study. It was noted that the usage of an inner heat exchanger in a cooling system increases the energy efficiency of both refrigerants. Matu-Royo et al. (2021) [8] have examined R1234ze(E) and R515B refrigerants with lower GWP instead of R134a in the heat pump system. They found that the energy and environmental performance of R1234ze(E) and R515B are almost the same as that of R134a and the lack of flammability of R515B is an important advantage in terms of safety. Kumar (2018) [9] examined the energetic and exergetic analyses of R134a, R1234ze(E), R1234yf and its mixtures in the vaporcompression system. It has been found that R134a /R1234yf /R1234ze(E) (\%40/\%22/\%38) mixture showed the best performance instead of R134a in his study. Prabakaran et al. (2020) [10] studied the performance and environmental analyses of mobile air conditioning systems which using R1234yf as a substitute for R134a. Also, compressor velocity on the energetic and exergetic efficiency of the system was investigated. They found that the R1234yf system has better COP and exergetic efficiency according to the R134a system. Bellman-Flores et al. (2017) [11] conducted energetic and exergetic study of R1234yf as a direct substitute for R134a in household refrigeration systems. They also noted that for both R134a and R1234yf, the irreversibilities are most intensed in the compressor. Jemaa et al. (2017) [12] have examined the energetic and exergetic analyses of the use of R1234ze(E) and R134a refrigerants in a vapor-compression cooling system. The energetic and exergetic efficiency of R134a and R1234ze are very similar. Saravanakumar and Selladurai (2014) [1] used a mixture of refrigerant R290/R600a as a substitute for R134a, and conducted an exergy analysis of household refrigerators. In general, the experimental household refrigeration system using
R600a/R290 mixed refrigerant has better performance than using R134a as the refrigerant. Yatagambaba et al. (2015) [13] performed exergetic analyses of R1234ze(E) and R1234yf replace to R134a in a vapor-compression cooling system which has a double evaporator. In their studies, the effects of condenser and evaporator temperature on exergy loss and system exergy efficiency were examined. Gil et al (2018) [14] have investigated the exergetic analysis of the use of refrigerants R450A and R134a in a cooling system. In the study, they stated that under the same conditions, R450A refrigerant gave better results than R134a. Shaik et al. (2020) [15] examined the energetic and exergetic analyses on R1234yf and R152a refrigerants instead of R134a in a hausehold refrigerators. They have stated that 152a and R1234yf refrigerants may well replace R134a refrigerants without any modification. Paula et al. (2020) [16] performed energetic, exergetic and environmental analyses of the use of R290, R1234yf and R744 refrigerants instead of R134a refrigerant in a vapor-compression cooling cycle. Mota-Babiloni et al. (2017) [17] provided literature information to review some curious aspects regarding the useage of new pure synthetic refrigerants and hybrid synthetic refrigerants to replace HFCs, which have a greater impact on the environment. Perez-Garcia et al. (2017) [18] carried out the exergy analysis of MAC (mobile air-conditioning) system that use inner heat exchangers (IHX) and R134a instead of refrigerants. It was also found that when R1234ze refrigerant is used, the operating efficiency of the system is the highest. Gorzari et al. (2017) [19] compared the performance of the R134a refrigerant with that of the R1234yf refrigerant in a automobile refrigeration system. Compared with R134a, the use of $\mathrm{R} 1234 \mathrm{yf}$ as an air-conditioning refrigerant can bring out a higher exergy efficiency.

As can be seen from the studies in the literature, energy, exergy, and optimization works relative to the use of different refrigerants with lower GWP ratios than R134a in systems operating with the vapor-compression cycles have been carried out by a lot of researchers. Nevertheless, there is a lack of studies on the examination of vaporcompression systems using the new mixture refrigerant $\mathrm{R} 515 \mathrm{~B}$ in the literature. As R134a is about to be phased out in favor of R515B or any other suitable alternative.

This study aims to perform an energetic, exergetic, environmental and enviroeconomic analyzes and comparison of the use of R134a and R515B with an internal heat exchanger in a refrigeration system. 


\section{Analysis of Energy and Exergy}

Figure 1 schematically shows the components of the vapour compression refrigeration system (VCR) which has an internal heat exchanger (IHX).

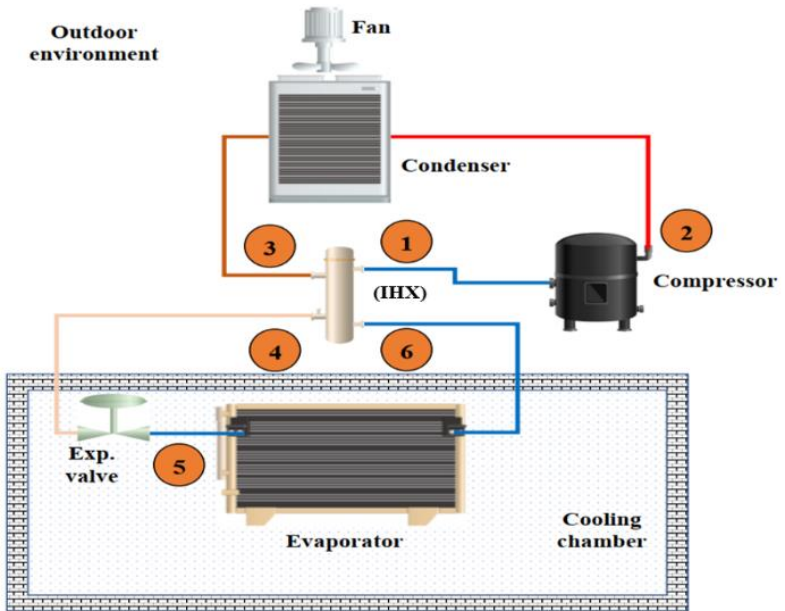

Figure 1. The vapor-compression refrigeration system diagram.

To effectively compare the application ranges of R515B and R134a, the P-T (pressure-temperature) and P-h (pressure-enthalpy) diagrams are given in Figure 2 and Figure 3, respectively. The saturation temperatures corresponding to the working pressures of the alternative refrigerants should be the same as or close to the refrigerant to be used instead. As seen in Figure 2, while the saturation pressures of R134a and R515B at low temperatures are very close, the saturation pressure of R134a at high temperatures is slightly higher than R515B.

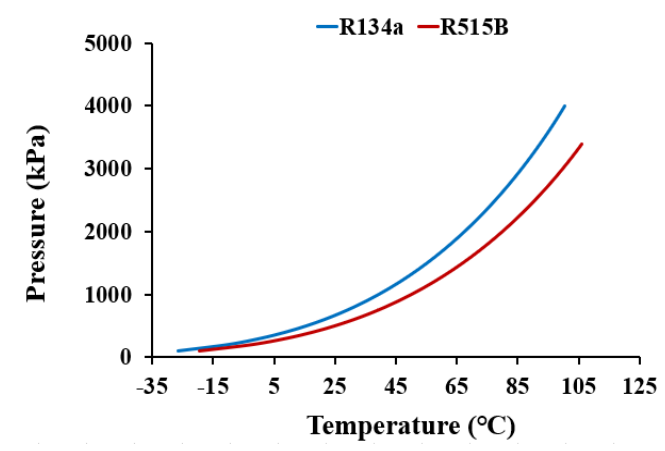

Figure 2. $P$ - T diagram of R134a and R515B

The refrigerating effect (evaporator inlet and outlet enthalpy difference) affects the cooling capacity. The refrigerating effect of R134a at a pressure of 200, 400, 600, and $800 \mathrm{kPa}$ is $206.02 \mathrm{~kJ} / \mathrm{kg}, 191.61 \mathrm{~kJ} / \mathrm{kg}, 180.89 \mathrm{~kJ} / \mathrm{kg}$, and $171.81 \mathrm{~kJ} / \mathrm{kg}$, respectively. For the same pressure values, the refrigerating effect of $\mathrm{R} 515 \mathrm{~B}$ is $179.77 \mathrm{~kJ} / \mathrm{kg}$, $166.63 \mathrm{~kJ} / \mathrm{kg}, 156.73 \mathrm{~kJ} / \mathrm{kg}$, and $148.28 \mathrm{~kJ} / \mathrm{kg}$, respectively. The refrigerating effect of R515B is lower about \%15.50 than that of R134a.

A computational model of vapor-compression cooling system with inner heat exchanger (IHX) has been developed to perform the thermodynamics and environmental analyses. The assumptions made to carry out this study are listed in Table 2. The REFPROP 9.1 [20] was used to obtain the refrigerant's properties.

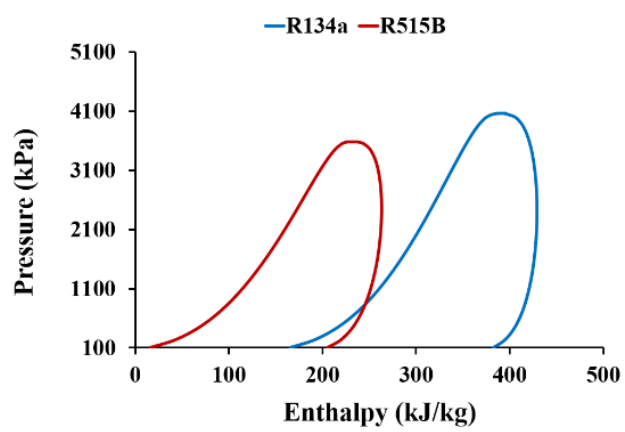

Figure 3. P-h diagram of R134a and R515B.

Table 2. Some acceptances for the analyses.

\begin{tabular}{|c|c|}
\hline Parameter & Value \\
\hline Temperature of evaporator $\left(T_{e}\right)$ & $\begin{array}{l}\left(-20{ }^{\circ} \mathrm{C}, 5{ }^{\circ} \mathrm{C}\right) \text { at steps } \\
\text { of } 5{ }^{\circ} \mathrm{C}\end{array}$ \\
\hline Temperature of condenser $\left(T_{c}\right)$ & $40^{\circ} \mathrm{C}$ and $45^{\circ} \mathrm{C}$ \\
\hline$\left(\Delta \mathrm{T}_{\text {superheat }}\right)$ & $5^{\circ} \mathrm{C}$ \\
\hline ing $\left(\Delta \mathrm{T}_{\text {subcooling }}\right)$ & $5^{\circ} \mathrm{C}$ \\
\hline $\begin{array}{l}\text { Temperature difference between condenser } \\
\text { and heat sink }\left(\Delta \mathrm{T}_{\text {heat, }, \text { sink }}\right)\end{array}$ & $10^{\circ} \mathrm{C}$ \\
\hline $\begin{array}{l}\text { Temperature difference between evaporator } \\
\text { and heat source }\left(\Delta T_{\text {heat,source }}\right)\end{array}$ & $10^{\circ} \mathrm{C}$ \\
\hline Compressor isentropic efficiency $\left(\eta_{\text {isen }}\right)$ & 0.70 \\
\hline Compressor sweep volume & 26.11 \\
\hline $\begin{array}{l}\text { Dead-state pressure }\left(\mathrm{P}_{0}\right) \text { and temperature } \\
\left(\mathrm{T}_{0}\right)\end{array}$ & $101.325 \mathrm{kPa}$ an \\
\hline
\end{tabular}

The equations used in energy and exergy analyses are reproduced from the law of preservation of mass and energy. The compressor energy consumption can be calculated by the following Eqs. (1) - (5):

$\dot{\mathrm{W}}_{\text {comp }}=\dot{\mathrm{m}}_{\mathrm{r}}\left(\mathrm{h}_{2}-\mathrm{h}_{1}\right)$

$\mathrm{h}_{2}=\mathrm{h}_{1}+\frac{\left(\mathrm{h}_{2 \mathrm{~s}}-\mathrm{h}_{1}\right)}{\eta_{\text {isen }}}$

The cooling capacity is calculated as follows:

$\dot{\mathrm{Q}}_{\text {evap }}=\dot{\mathrm{m}}_{\mathrm{r}}\left(\mathrm{h}_{6}-\mathrm{h}_{5}\right)$

The coefficient of performance for the cooling mode (COP) is written as:

$\mathrm{COP}=\frac{\text { Cooling capacity }}{\text { Compressor power consumption }}=\frac{\dot{\mathrm{m}}_{\mathrm{r}}\left(\mathrm{h}_{6}-\mathrm{h}_{5}\right)}{\dot{\mathrm{m}}_{\mathrm{r}}\left(\mathrm{h}_{2}-\mathrm{h}_{1}\right)}$

The refrigerant mass flow rate $\left(\dot{\mathrm{m}}_{\mathrm{r}}\right)$ is be calculated by:

$\dot{\mathrm{m}}_{\mathrm{r}}=\mathrm{V}_{\mathrm{s}} \rho_{1} \mathrm{RPM} \frac{\eta_{\mathrm{vol}}}{60}$

Exergy analysis provides a quantitative measure of the inefficiency of cooling systems and information about exergy destruction. Assuming that the variation in the potential energy and kinetic energy can be ignored, the specific exergy is written as:

$e x_{i}=\left(h_{i}-h_{0}\right)-T_{0}\left(s_{i}-s_{0}\right)$

at the ambient temperature (dead-state), $\mathrm{T}_{0}$.

The total exergy balance equation of the compressor is given by:

$\sum(\dot{\mathrm{m}} \mathrm{ex})_{\text {in }}+\dot{\mathrm{W}}_{\text {comp }}=\sum(\dot{\mathrm{m}} \mathrm{ex})_{\text {out }}+\dot{\mathrm{Ex}}_{\text {dest,comp }}$ 
$\dot{\mathrm{E}}_{1}-\dot{\mathrm{E}}_{2}+\dot{\mathrm{W}}_{\text {comp }}-\dot{\mathrm{Ex}}_{\mathrm{dest}, \mathrm{comp}}=0$

$\dot{\mathrm{Ex}} \mathrm{dest}_{\text {demp }}=\dot{\mathrm{m}}_{\mathrm{r}}\left[\left(\mathrm{h}_{1}-\mathrm{h}_{2}\right)-\mathrm{T}_{0}\left(\mathrm{~s}_{1}-\mathrm{s}_{2}\right)\right]+\dot{\mathrm{W}}_{\text {comp }}$

Where $\dot{E x}_{\text {dest,comp }}$ is the exergy destruction rate of the compressor. The general exergy balance equation of the condenser is given by Eq. (10).

$\sum(\dot{\mathrm{m}} \mathrm{ex})_{\mathrm{in}}=\sum(\dot{\mathrm{m}} \mathrm{ex})_{\mathrm{out}}+\dot{\mathrm{Ex}} \mathrm{x}_{\mathrm{th}, \text { cond }}+\dot{\mathrm{E}} \mathrm{x}_{\mathrm{dest}, \mathrm{cond}}$

Where $\dot{E x}_{\text {th,cond }}$ is the thermal exergy ratio of condenser. Calculation of thermal exergy is carried out by Equation (11).

$\dot{\mathrm{Ex}} \mathrm{thh}_{\text {tond }}=\left(1-\frac{\mathrm{T}_{0}}{\mathrm{~T}_{\mathrm{H}}}\right) \dot{\mathrm{Q}}_{\text {cond }}$

$\dot{\mathrm{E}}_{2}-\dot{\mathrm{E}}_{3}+\left(1-\frac{\mathrm{T}_{0}}{\mathrm{~T}_{\mathrm{H}}}\right) \dot{\mathrm{Q}}_{\text {cond }}-\dot{\mathrm{Ex}}_{\mathrm{dest}, \text { cond }}=0$

$\dot{E} \mathrm{x}_{\text {dest,cond }}=\dot{\mathrm{m}}_{\mathrm{r}}\left[\left(\mathrm{h}_{2}-\mathrm{h}_{3}\right)-\mathrm{T}_{0}\left(\mathrm{~s}_{2}-\mathrm{s}_{3}\right)\right]-$

$\left(1-\frac{\mathrm{T}_{0}}{\mathrm{~T}_{\mathrm{H}}}\right) \dot{\mathrm{Q}}_{\text {cond }}$

Where $\dot{E x}_{\text {dest,cond }}$ is the exergy destruction of the condenser. For the evaporator, the overall exergy balance equation is written as:

$\sum(\dot{\mathrm{m}} \mathrm{ex})_{\mathrm{in}}+\dot{\mathrm{Ex}}_{\mathrm{th}, \mathrm{evap}}=\sum(\dot{\mathrm{m}} \mathrm{ex})_{\text {out }}+\dot{\mathrm{Ex}}_{\mathrm{dest}, \mathrm{evap}}$

Where $E x_{\text {th,evap }}$ represents the thermal exergy of evaporator. The thermal exergy is be calculated by Eq. (15) as follows:

$\dot{E x}_{\text {th,evap }}=\left(1-\frac{T_{0}}{T_{L}}\right) \dot{Q}_{\text {evap }}$

$\dot{\mathrm{E}}_{5}-\dot{\mathrm{E}}_{6}+\left(1-\frac{\mathrm{T}_{0}}{\mathrm{~T}_{\mathrm{L}}}\right) \dot{\mathrm{Q}}_{\mathrm{evap}}-\dot{\mathrm{Ex}}_{\text {dest,evap }}=0$

$\dot{\mathrm{E}_{\text {dest,evap }}}=\dot{\mathrm{m}}_{\mathrm{r}}\left[\left(\mathrm{h}_{5}-\mathrm{h}_{6}\right)-\mathrm{T}_{0}\left(\mathrm{~s}_{5}-\mathrm{s}_{6}\right)\right]+$

$\left(1-\frac{\mathrm{T}_{0}}{\mathrm{~T}_{\mathrm{L}}}\right) \dot{\mathrm{Q}}_{\mathrm{evap}}$

Where $\dot{E x}_{\text {dest,evap }}$ is the exergy destruction of the evaporator. For the expansion valve the total exergy balance equation is written as:

$\sum(\dot{\mathrm{m}} \mathrm{ex})_{\text {in }}=\sum(\dot{\mathrm{m}} \mathrm{ex})_{\text {out }}+\dot{\mathrm{Ex}}_{\mathrm{dest}, \exp }$

$\dot{\mathrm{E}}_{4}-\dot{\mathrm{E}}_{5}-\dot{\mathrm{Ex}}_{\mathrm{dest}, \exp }=0$

$\dot{\mathrm{Ex}}_{\mathrm{dest}, \exp }=\dot{\mathrm{m}}_{\mathrm{r}}\left[\mathrm{T}_{0}\left(\mathrm{~s}_{5}-\mathrm{s}_{4}\right)\right]$

Where $\dot{E} x_{\text {dest,exp }}$ shows off the expansion valve's exergy destruction. Adding up the exergy destruction of whole the components of the cooling system, the total exergy destruction is as follows:

$\dot{E} x_{\text {dest,total }}=\dot{E} \dot{x}_{\text {dest,comp }}+\dot{E} \dot{x}_{\text {dest,cond }}+\dot{E x}_{\text {dest,evap }}+$

Ex $x_{\text {dest,exp }}$
For the cooling system, the total exergetic efficiency $\left(\eta_{\mathrm{ex}}\right)$ can be calculated by Eq. (22).

$\eta_{\text {ex }}=\frac{\dot{\mathrm{E}}_{\text {out }}}{\dot{\mathrm{E}}_{\text {in }}}=1-\frac{\dot{E} x_{\text {dest,total }}}{\dot{\mathrm{E}}_{\text {in }}}=1-\frac{\dot{E x}_{\text {dest,total }}}{\dot{\mathrm{W}}_{\text {comp }}}$

\section{Environmental and Enviroeconomic Analyses}

Environmental analysis gives the emission of a system as " $\mathrm{kgCO} 2 / \mathrm{time}$ " in a certain time period depending on the energy consumption of a system. Here, the production emission $\left(\mathrm{kgCO}_{2} / \mathrm{kWh}\right)$ of the electrical energy consumed by the system is important. Environmental analysis can be calculated by Eq. (23) [21], [22].

$\mathrm{X}_{\mathrm{CO}_{2}}=\mathrm{EM} \dot{\mathrm{E}}_{\mathrm{in}} \mathrm{t}_{\text {working }}$

$\mathrm{X}_{\mathrm{CO}_{2}}$ represents the greenhouse gas emission $\left(\mathrm{kgCO}_{2} /\right.$ time $)$ released for a certain period of time, the emission value of the energy source option used in EM electricity generation $\left(\mathrm{kgCO}_{2} / \mathrm{kWh}\right)$, the energy consumption of the $\dot{\mathrm{E}}_{\mathrm{in}}$ system $(\mathrm{kW})$ and the $\mathrm{t}_{\text {working }}$ in a period of time (hour/time). It shows the operating time (hour/time) of the system.

Carbon pricing is one of the effective methods used to evaluate the greenhouse gas emissions caused by a system. Enviroeconomic analysis is based on environmental analysis $\left(\mathrm{kgCO}_{2} /\right.$ time $)$ and greenhouse gas emission price $\left(\$ / \mathrm{kgCO}_{2}\right)$. Enviroeconomic analysis can be calculated with Eq. (24) [21], [22].

$\mathrm{C}_{\mathrm{CO}_{2}}=\mathrm{c}_{\mathrm{CO}_{2}} \mathrm{X}_{\mathrm{CO}_{2}}$

$\mathrm{X}_{\mathrm{CO}_{2}}$ shows the environmental analysis result ( $\left.\mathrm{kgCO}_{2} / \mathrm{time}\right), \mathrm{C}_{\mathrm{CO}_{2}}$ the price of greenhouse gas emission $\left(\$ / \mathrm{kgCO}_{2}\right)$ and $\mathrm{C}_{\mathrm{CO}_{2}}$ the result of enviroeconomic analysis (\$/time). In Table 3, some assumptions made for environmental and enviroeconomic analyses are dedicated.

Table 3. Assumptions for environmental and enviroeconomic analyses.

\begin{tabular}{ll}
\hline Description & Value \\
\hline Cooling capacity & $5 \mathrm{~kW}$ \\
$\mathrm{t}_{\text {working }}$ & $12 \mathrm{~h} /$ day \\
$\mathbf{c}_{\mathrm{CO}_{2}}$ & $0.0145 \$ / \mathrm{kgCO}_{2}[21],[22]$ \\
$\mathrm{EM}$ & $0.523 \mathrm{kgCO}_{2} / \mathrm{kWh}[23]$ \\
\hline
\end{tabular}

\section{Results and Discussions}

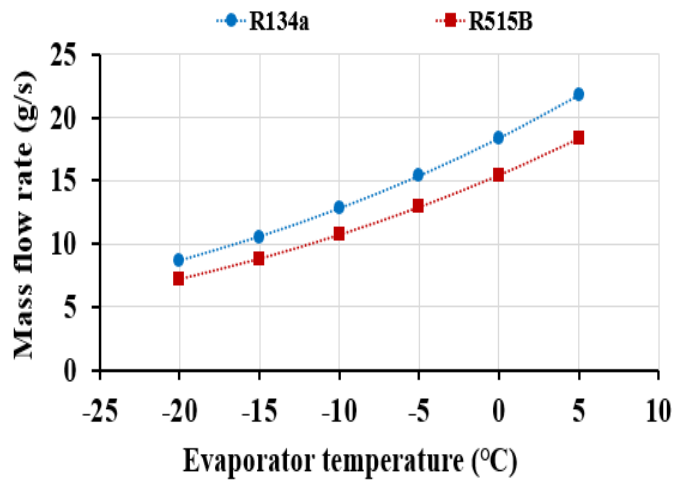

Figure 4. Evaporator temperature-dependent changing of mass flow rate of $R 134 a$ and $R 515 B$. 
VCR with an inner heat exchanger was used to evaluate the performances of R134a and R515B. The comparison of the mass flow rates of R134a and R515B is given in Figure 4. The mass flow rates of R134a and R515B increased as the evaporator temperature increased: from $8.65 \mathrm{~g} / \mathrm{s}$ to $21.79 \mathrm{~g} / \mathrm{s}$ for R134a and from $7.21 \mathrm{~g} / \mathrm{s}$ to $18.35 \mathrm{~g} / \mathrm{s}$ for $\mathrm{R} 515 \mathrm{~B}$. The mass flow rate of R515B is lower than that of $\mathrm{R} 134 \mathrm{a}$. It is due to the fact that R515B in the suction line has a lower vapor density than R134a. For both refrigerants, the mass flow rate is not affected by the condenser temperature.

Using R134a and R515B refrigerants in the refrigeration system, the effect of the temperature of the evaporator on compressor energy consumption is presented in Figure 5. While the condenser temperature is $40{ }^{\circ} \mathrm{C}$, the compressor power consumption of R134a varies from $538.42 \mathrm{~W}$ to $709.66 \mathrm{~W}$, while the compressor power consumption of $\mathrm{R} 515 \mathrm{~B}$ from $392.42 \mathrm{~W}$ to $529.84 \mathrm{~W}$. While the condenser temperature is $45^{\circ} \mathrm{C}$, the compressor power consumption of R134a varies between 574.48 $\mathrm{W}$ and $797.69 \mathrm{~W}$, while the compressor power consumption of R515B varies between $417.96 \mathrm{~W}$ and $594.63 \mathrm{~W}$. The compressor specific compression work and the mass flow rates of the refrigerants affect the energy consumption of the compressor. The specific compression work and mass flow rate of R134a are higher compared to R515B. That's why as seen in Figure 5, the compressor energy consumption of $\mathrm{R} 134 \mathrm{a}$ is higher than that of R515B. Because the mass flow rates increases as the temperature of the evaporator rises, the refrigeration system's power consumption rises.

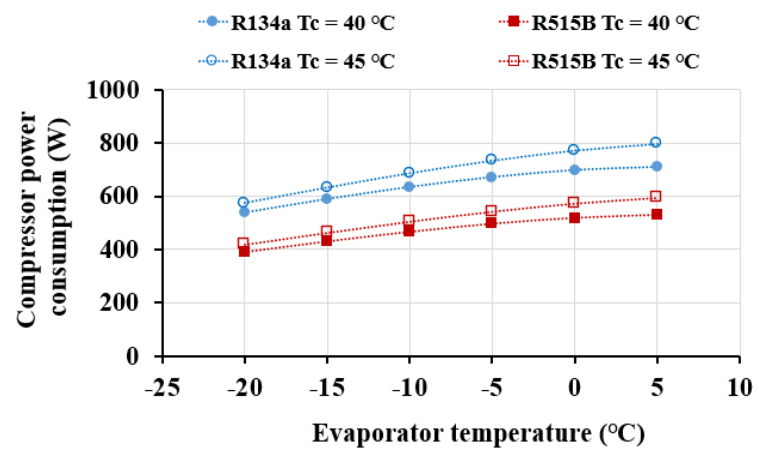

Figure 5. Evaporator temperature-dependent changing of compressor power consumption of R134a and R515B.

The compressor capacity is greatly affected by the cooling capacity. The cooling effect (the difference in enthalpy of the refrigerant entering and leaving the evaporator) and the mass flow rate of the refrigerant affect the cooling capacity. Figure 6 gives the cooling capacity variation to different evaporator temperatures for $\mathrm{R} 134 \mathrm{a}$ and $\mathrm{R} 515 \mathrm{~B}$ at two condenser temperatures $\left(40^{\circ} \mathrm{C}\right.$ and $\left.45^{\circ} \mathrm{C}\right)$. R134a refrigerant has a higher cooling capacity than R515B. Because both the cooling effect and the refrigerant mass flow rate of $\mathrm{R} 134 \mathrm{a}$ are higher than that of $\mathrm{R} 515 \mathrm{~B}$. When the condenser temperature is $40^{\circ} \mathrm{C}$, the cooling capacity of R134a varies from $1224.89 \mathrm{~W}$ to $3422.58 \mathrm{~W}$, while the cooling capacity of $\mathrm{R} 515 \mathrm{~B}$ varies from $879.21 \mathrm{~W}$ to $2554.31 \mathrm{~W}$. When the condenser temperature is $45{ }^{\circ} \mathrm{C}$, the cooling capacity of $\mathrm{R} 134 \mathrm{a}$ varies from $1160.98 \mathrm{~W}$ to $3261.56 \mathrm{~W}$, while the cooling capacity of R515B varies from $828.28 \mathrm{~W}$ to $2424.76 \mathrm{~W}$. It has been observed that the cooling capacity of both refrigerants decreases when the condenser temperature increases. Because when the condenser temperature increases, the enthalpy of the refrigerant entering the evaporator increases, so that the cooling effect decreases.

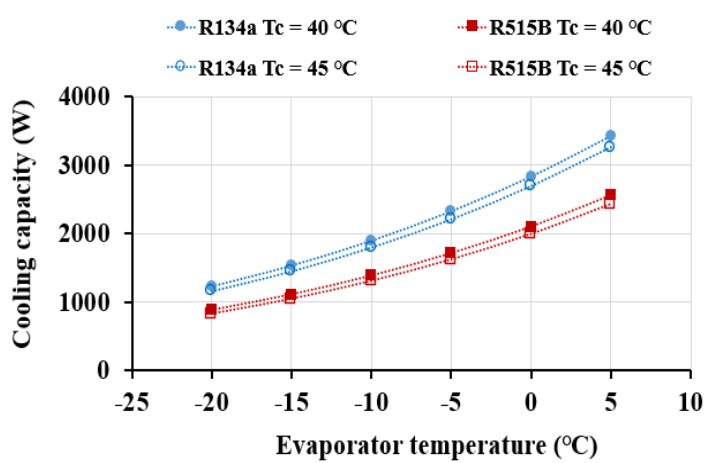

Figure 6. Evaporator temperature-dependent changing of cooling capacity of R134a and R515B

Figure 7 shows the COP of R134a and R515B refrigerants depending on the evaporator temperature at condenser temperatures of $40^{\circ} \mathrm{C}$ and $45^{\circ} \mathrm{C}$. While the condenser temperature is $40{ }^{\circ} \mathrm{C}$, the COP of $\mathrm{R} 134$ a varies from 2.27 to 4.82 , while the COP of R515B from 2.24 to $4.82 \mathrm{~W}$. While the condenser temperature is $45^{\circ} \mathrm{C}$, the COP of R134a varies between 2.02 and 4.09, while the COP of $\mathrm{R} 515 \mathrm{~B}$ varies between 1.98 and 4.08 . It is found that the COP obtained by using R515B refrigerant is nearly equal to the COP obtained by using R134a. This is because although the cooling capacity of R515B refrigerant is less than that of R134a refrigerant, the compressor power consumption of $\mathrm{R} 515 \mathrm{~B}$ refrigerant is lower than that of $\mathrm{R} 134 \mathrm{a}$ refrigerant. The COP value of both refrigerants decreases as the temperature of the condenser rises.

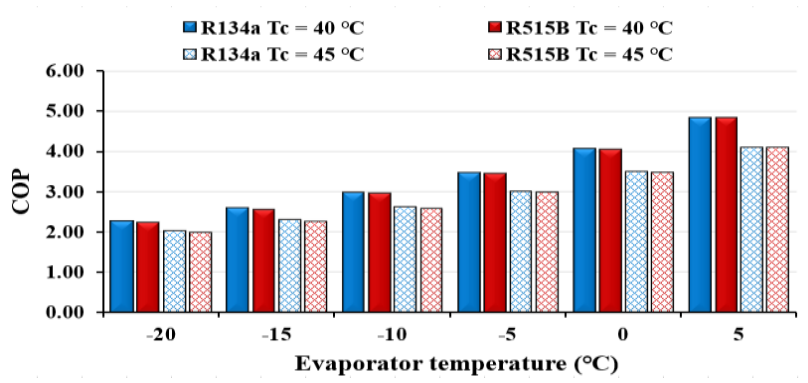

Figure 7. Column chart of COPs of R134a and R515B

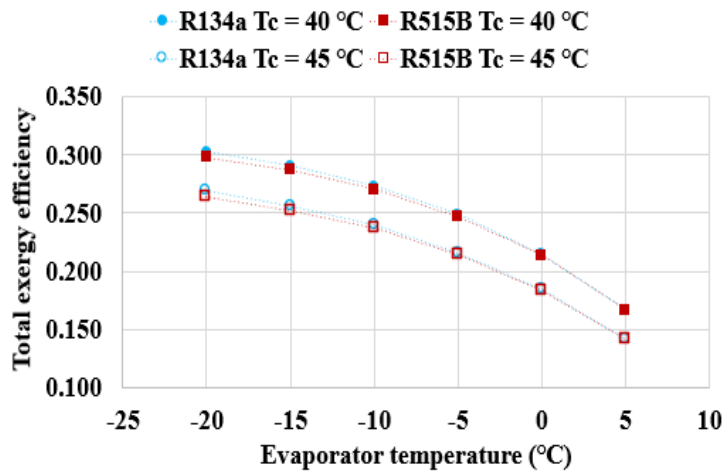

Figure 8. Evaporator temperature-dependent changing of total exergy efficiency of R134a and R515B

The changing of the total exergy efficiencies of R134a and $\mathrm{R} 515 \mathrm{~B}$ at different evaporator and condenser temperatures is demonstrated in Figure 8. As the evaporator temperature increases, the irreversibilities of the cooling system compenents increase, and consequently the exergy 
efficiency of the cooling system decreases. The total exergy efficiency of R134a refrigerant at low evaporator temperature is slightly higher (about $1.40 \%$ ) than that of $\mathrm{R} 515 \mathrm{~B}$ refrigerant, the total exergy efficiency of $\mathrm{R} 134 \mathrm{a}$ is the same as that of $\mathrm{R} 515 \mathrm{~B}$ refrigerant at high evaporator temperature.

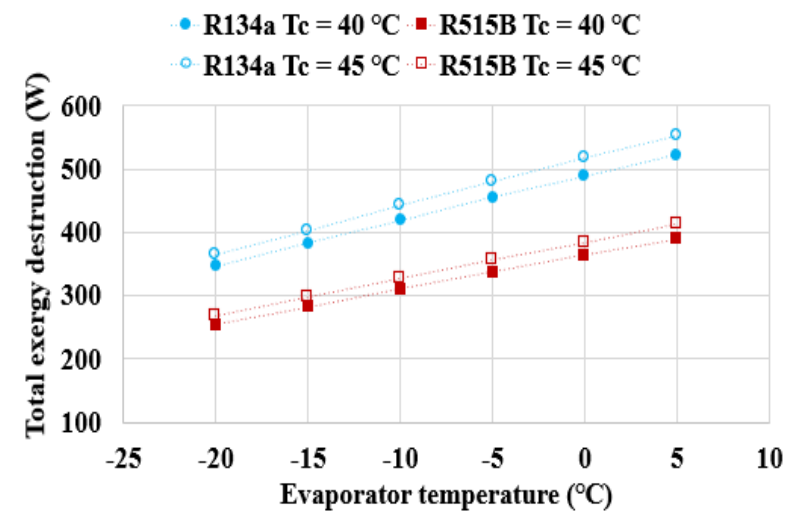

Figure 9. Evaporator temperature-dependent change in total exergy destructions of R134a and R515B

The change in total exergy destruction in case of using refrigerants R134a and R515B in the refrigeration system at different evaporator and condenser temperatures is shown in Figure 9. At a condenser temperature of $40{ }^{\circ} \mathrm{C}$, the total exergy destruction of the refrigeration system using R134a in the refrigeration system varies from $346.42 \mathrm{~W}$ to 522.73 $\mathrm{W}$, while the total exergy destruction of the refrigeration system using R515B in the refrigeration system varies from $254.51 \mathrm{~W}$ to $390.33 \mathrm{~W}$. At a condenser temperature of 45 ${ }^{\circ} \mathrm{C}$, the total exergy destruction of the refrigeration system using R134a in the refrigeration system varies from 363.75 $\mathrm{W}$ to $552.77 \mathrm{~W}$, while the total exergy destruction of the refrigeration system using $\mathrm{R} 515 \mathrm{~B}$ in the refrigeration system varies from $267.36 \mathrm{~W}$ to $412.49 \mathrm{~W}$. When R134a is used in the refrigeration system, the total exergy destruction is about $26 \%$ higher than when $\mathrm{R} 515 \mathrm{~B}$ is used in the refrigeration system. Also, the total exergy destruction of the system increases due to the increase in irreversibilities, as the condenser temperature increases.
In the case where refrigerants $\mathrm{R} 134 \mathrm{a}$ and $\mathrm{R} 515 \mathrm{~B}$ are used in the refrigeration system, the exergy destruction of all components is shown in Figure 10. As can be seen in Figure 10, for both refrigerants the exergy destruction takes place mainly in the compressor. For both refrigerants, the component with the least exergy destruction at low evaporator temperatures is the evaporator, while the component with the least exergy destruction at high evaporator temperatures is the expansion valve. As the expansion valve is only affected by the entropy change between the evaporator and condenser pressure, there is generally lower exergy destruction in expansion valve. As the evaporator temperature increases in the expansion valve, the entropy production decreases. therefore, the exergy destruction of the expansion valve is reduced. As the evaporator temperature decreases, the exergy destruction of the expansion valve increases. Therefore, at low evaporator temperatures the minimum exergy destruction occurred in evaporator.

The comparison of compressor exergy destruction in the case of using R134a and R515B refrigerants in the cooling system is shown in Figure 11. The exergy destruction of the compressor for both refrigerant increase as the evaporator temperature increases. This is because as the evaporator temperature rises, the mass flow rate increases, and the compressor uses higher exergy. It was seen that the compressor exergy destruction of R515B refrigerant is lower (about 24\%) than that of $\mathrm{R} 134 \mathrm{a}$ refrigerant. Due to the thermal properties of $\mathrm{R} 515 \mathrm{~B}$, the entropy generation in the compressor during compression is lower than that of R134a.

The comparison of the condenser exergy destruction of the cooling system for R134a and R515B is presented in Figure 12. It was explained above that the mass flow rates of the refrigerants increase with increasing evaporator temperature increases. Consequently, the exergy destruction of the condenser also increases with increasingevaporator temperature. When refrigerant $\mathrm{R} 515 \mathrm{~B}$ is used in the refrigeration system, the exergy destruction of the condenser is about $32.50 \%$ lower than that of R134a . This is since the condenser entropy difference of $\mathrm{R} 134 \mathrm{a}$ is higher than that of R515B.

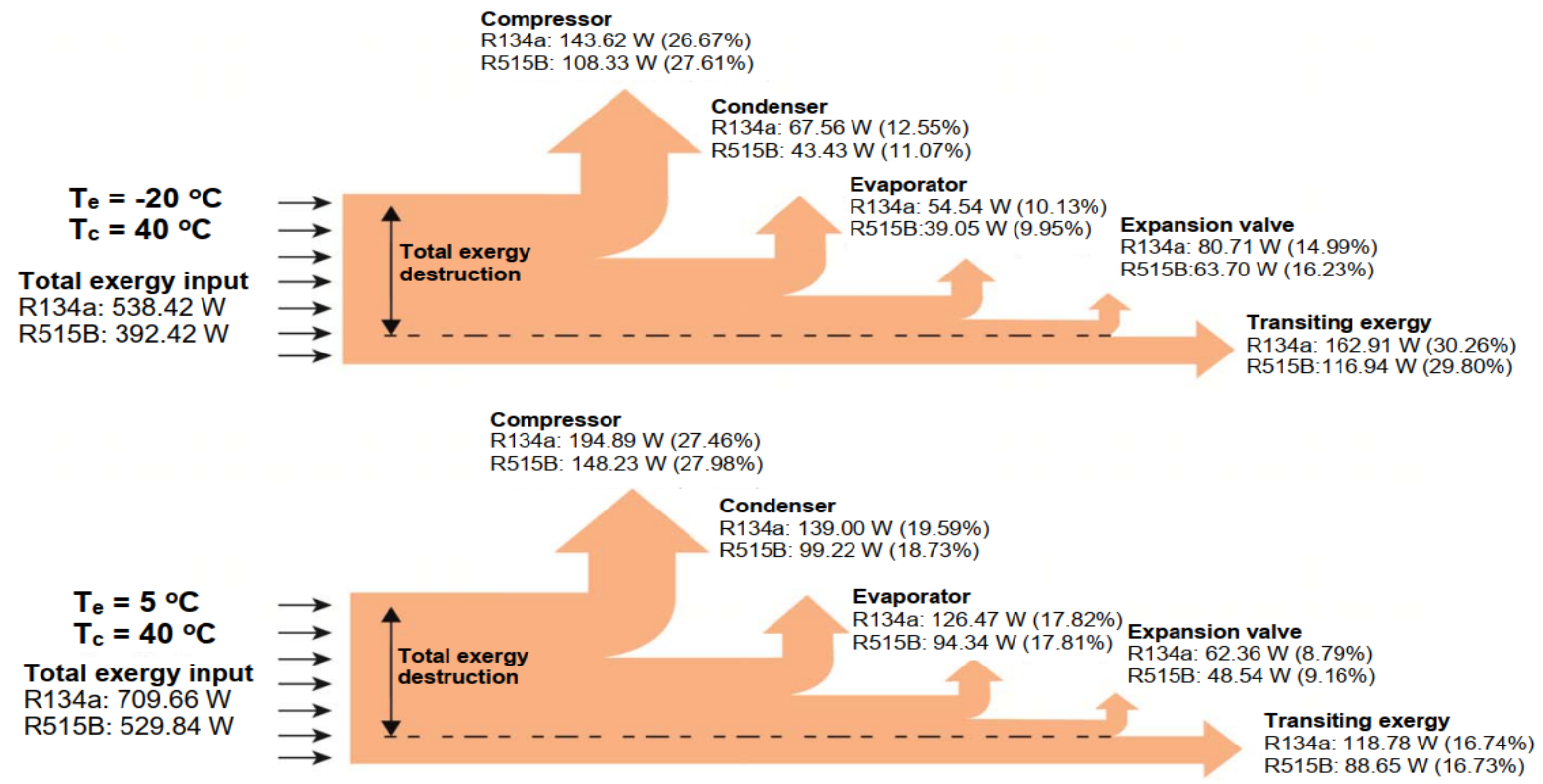

Figure 10. Graphical representation of all components's the exergy destruction for the refrigerants $R 134$ a and $R 515 B$. 


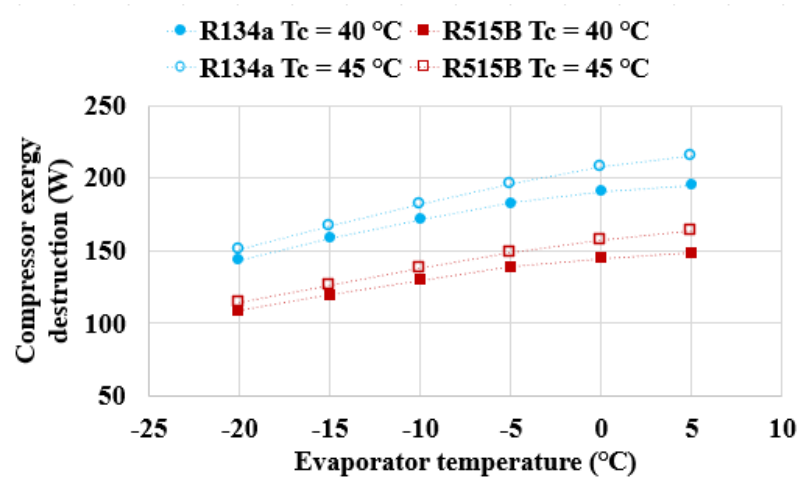

Figure 11. Evaporator temperature-dependent changing of compressor exergy destruction of R134a and R515B.

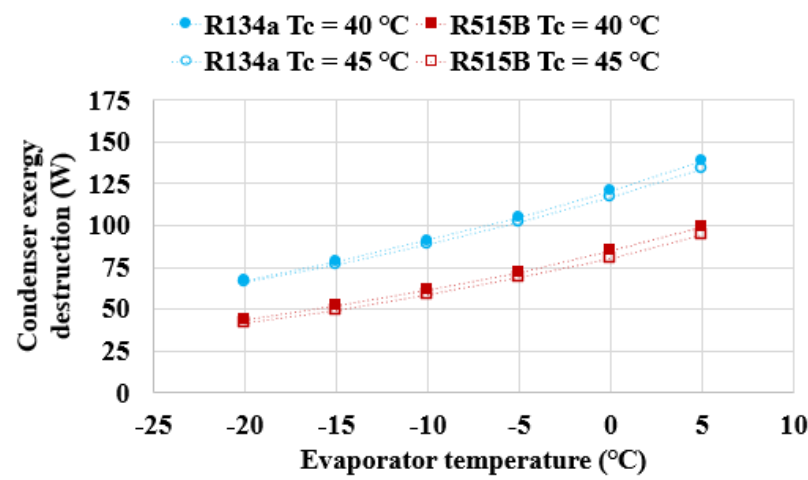

Figure 12. Evaporator temperature-dependent changing of condenser exergy destruction of R134a and R515B.

The comparison of the expansion valve exergy destruction of the cooling system for R134a and R515B is presented in Figure 13. The exergy destruction in the expansion valve decreases while the evaporator temperature rises. Because as the evaporator temperature rises in the expansion valve, the entropy production decreases. Therefore, the exergy destruction of the expansion valve reduces. It was found that the exergy destruction of the expansion valve was lower (about 21.50\%) for the refrigerant $\mathrm{R} 515 \mathrm{~B}$ than for the refrigerant $\mathrm{R} 134 \mathrm{a}$. This is because when R515B is used in the refrigeration system, the entropy difference of the expansion valve and the mass flow rate of the refrigerant are lower compared to R134a.

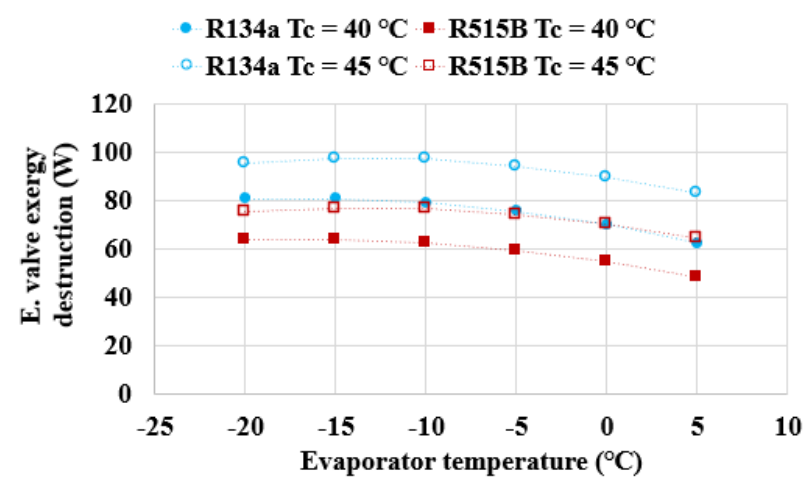

Figure 13. Evaporator temperature-dependent changing of expansion valve exergy destruction of R134a and R515B.

In Figure 14, comparing of the evaporator exergy destruction of refrigerants is given. When the evaporator temperature increases, the entropy generation in the evaporator increases. Therefore, as the evaporator temperature increases, the exergy destruction of the evaporator also increases. When using the refrigerant $\mathrm{R} 515 \mathrm{~B}$ in the cooling system, the exergy destruction of the evaporator is about $27 \%$ lower than with R134a. Because both the mass flow rate and entropy production of R515B are lower compared to R134a.

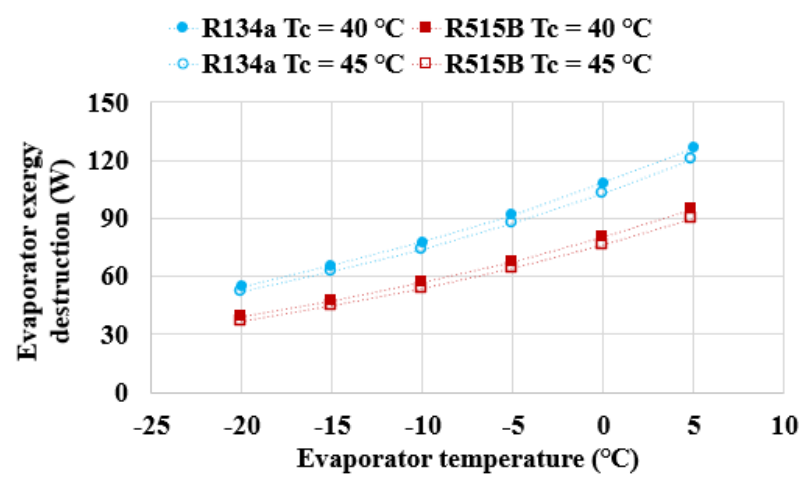

Figure 14. Evaporator temperature-dependent changing of evaporator exergy destruction of R134a and R515B.

The environmental analysis results of the refrigeration system with the evaporator temperature is given in Figure 15. When the evaporator temperature for both refrigerants increases, the COP value of the refrigeration system increases and consequently the environmental analysis results decrease. It can be seen that the results of the environmental analysis of R134a and R515B are very close in Figure 15. When the condenser temperature increases for both refrigerants, the energy consumption of the refrigeration system compressor increases. Therefore, the environmental analysis results increase.

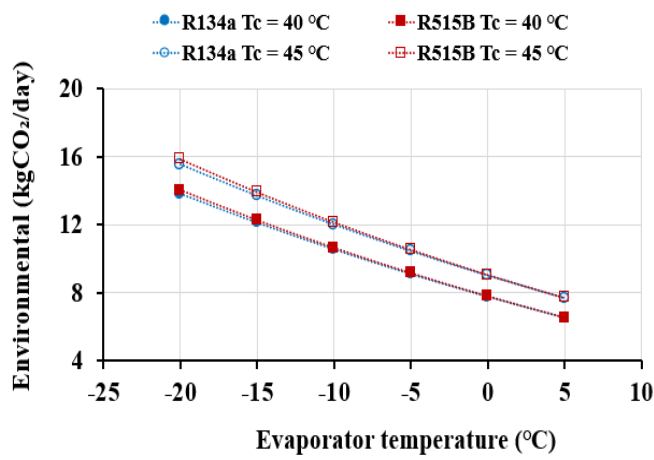

Figure. 15. Evaporator temperature-dependent changing of results obtained from environmental analysis.

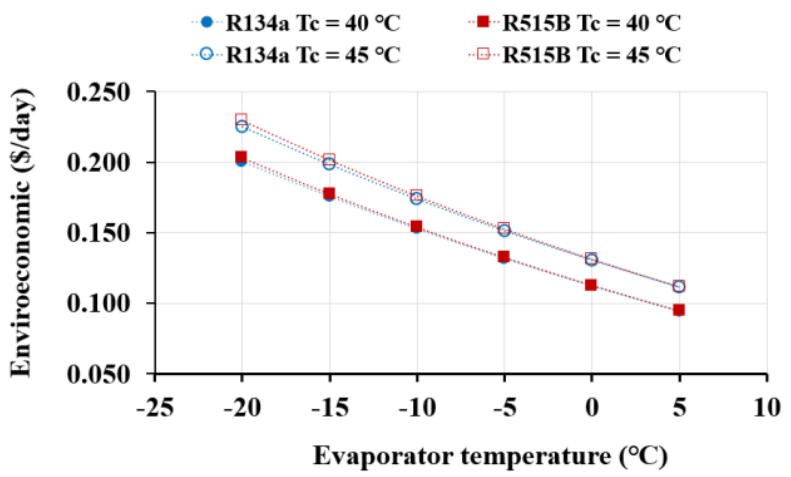

Figure. 16. Evaporator temperature-dependent changing of results obtained from enviroeconomic analysis.

The results of the environmental economic analysis depending on the evaporator and condenser temperatures 
are shown in Figure 16. As the evaporator temperature increases, the energy efficiency of the refrigeration system increases, and consequently, the energy consumption of the refrigeration system compressor decreases. Therefore, the results of the enviroeconomic analysis decrease as the evaporator temperature increases. It is seen that results obtained from the enviroeconomic analysis of R134a and $\mathrm{R} 515 \mathrm{~B}$ are very close to each other. Moreover, as the condenser temperature increases, the results of the enviroeconomic analysis increase similarly to the results of the environmental analysis, because the energy consumption of the cooling system increases.

\section{Conclusions}

In this work, the analysis of the R515B with lower GWP as replacements for R134a in a VCR system that has an IHX was made. Based on the energy, exergy, environmental and enviroeconomic analyses the main results obtained from the study are given below:

- $\mathrm{R} 515 \mathrm{~B}$ has lower mass flow rate, compressor energy consumption, and cooling capacity than that of R134a.

- In the refrigerating system, the COP obtained by using R515B refrigerant is nearly equal to the COP obtained by using R134a.

- Most exergy destruction occurs in the compressor of the refrigeration system.

- The compressor exergy destruction of the refrigeration system using $\mathrm{R} 515 \mathrm{~B}$ refrigerant is approximately $24 \%$ lower than that of R134a. The expansion valve exergy destruction of the refrigeration system using $\mathrm{R} 515 \mathrm{~B}$ refrigerant is approximately $21.50 \%$ lower than that of R134a.

- The condenser exergy destruction of the refrigeration system using $\mathrm{R} 515 \mathrm{~B}$ is about $32.50 \%$ lower than that of R134a.

- The exergy destruction of the evaporator of the refrigeration system using R515B is nearly $27 \%$ lower than that of R134a.

- Variation of evaporator and condenser temperatures greatly affects exergy destruction and exergy efficiency.

- It is found that the total exergy efficiency of the VCR system using R515B is slightly lower than that of R134a (about $1.40 \%$ ).

- The results of environmental and enviroeconomic evaluation based on energy analysis showed that $\mathrm{R} 515 \mathrm{~B}$ refrigerant was slightly higher than $\mathrm{R} 134 \mathrm{a}$ refrigerant.

Finally, R134a and R515B are slightly different in energy, exergy performance, environmental and enviroeconomic analysis. However, R515B has significant advantages in terms of installation safety requirements (no flammability (A1)) refrigerant). As a result, it has been shown that R515B can be a good alternative to R134a in VCR systems with an internal heat exchanger.

\section{Nomenclature \\ $\dot{\mathrm{W}}_{\text {comp }}$ Compressor power consumption [kW] \\ $\dot{\mathrm{m}}_{\mathrm{r}} \quad$ Refrigerant mass flow rate $\left[\mathrm{kg} \mathrm{s}^{-1}\right]$ \\ $\dot{\mathrm{Q}}_{\text {evap }}$ Cooling capacity $[\mathrm{kW}]$ \\ $\dot{\mathrm{Q}}_{\text {con }}$ Heating capacity $[\mathrm{kW}]$ \\ $\eta_{\text {isen }} \quad$ Compressor isentropic efficiency [-] \\ $\eta_{\text {vol }} \quad$ Compressor volumetric efficiency [-]}

\begin{tabular}{|c|c|}
\hline $\mathrm{h}$ & Enthalpy $\left[\mathrm{kJ} \mathrm{kg}^{-1}\right]$ \\
\hline $\mathrm{S}$ & Entropy $\left[\mathrm{kJ} \mathrm{kg}^{-1} \mathrm{~K}^{-1}\right]$ \\
\hline$\rho$ & Density $\left[\mathrm{kg} \mathrm{m}^{-3}\right]$ \\
\hline $\mathrm{T}$ & Temperature $\left[{ }^{\circ} \mathrm{C}\right.$ or $\left.\mathrm{K}\right]$ \\
\hline $\mathrm{P}$ & Pressure $[\mathrm{kPa}$ or bar $]$ \\
\hline $\mathrm{COP}$ & Coefficient of performance for cooling mode [-] \\
\hline$\dot{\mathrm{Ex}}$ & Exergy [kW] \\
\hline$\dot{\mathrm{E}}$ & Energy $[\mathrm{kW}]$ \\
\hline$\eta_{\mathrm{ex}}$ & Exergy efficiency [-] \\
\hline $\mathrm{COP}_{\mathrm{HP}}$ & Heat pump coefficient of performance [-] \\
\hline$t_{\text {working }}$ & Operation time (hour/time) \\
\hline $\mathrm{X}_{\mathrm{CO}_{2}}$ & Environmental analysis $\left[\mathrm{kgCO}_{2}\right.$ time $\left.^{-1}\right]$ \\
\hline EM & $\begin{array}{l}\text { Electricity energy production emission value } \\
{\left[\mathrm{kgCO}_{2} \mathrm{kWh}^{-1}\right]}\end{array}$ \\
\hline $\mathrm{C}_{\mathrm{CO}_{2}}$ & Environmentaleconomic analysis $\left[\mathrm{kgCO}_{2}\right.$ day $\left.^{-1}\right]$ \\
\hline $\mathrm{c}_{\mathrm{CO}_{2}}$ & Greenhouse gas emission price $\left[\$ \mathrm{kgCO}_{2}^{-1}\right]$ \\
\hline RPM & Revolutions per minute $\left[\right.$ Rev $\left.\mathrm{min}^{-1}\right]$ \\
\hline
\end{tabular}

\section{References:}

[1] R. Saravanakumar and V. Selladurai, "Exergy analysis of a domestic refrigerator using eco-friendly R290/R600a refrigerant mixture as an alternative to R134a," J. Therm. Anal. Calorim. 2013 1151, vol. 115, no. 1, pp. 933-940, June 2013.

[2] F. Molés, J. Navarro-Esbrí, B. Peris, A. Mota-Babiloni, and Á. Barragán-Cervera, "Theoretical energy performance evaluation of different single stage vapour compression refrigeration configurations using R1234yf and R1234ze(E) as working fluids," Int. J. Refrig., vol. 44, pp. 141-150, August 2014.

[3] Z. Yang et al., "Analysis of lower GWP and flammable alternative refrigerants," Int. J. Refrig., vol. 126, pp. 1222, Jun. 2021.

[4] P. Makhnatch, A. Mota-Babiloni, A. López-Belchí, and R. Khodabandeh, "R450A and R513A as lower GWP mixtures for high ambient temperature countries: Experimental comparison with R134a," Energy, vol. 166, pp. 223-235, January 2019.

[5] G. Li, "Performance evaluation of low global warming potential working fluids as R134a alternatives for twostage centrifugal chiller applications," Korean J. Chem. Eng, vol. 38, no. 7, pp. 1438-1451, 2021.

[6] J. U. Ahamed, R. Saidur, H. H. Masjuki, and M. A. Sattar, "An Analysis of Energy, Exergy, and Sustainable Development of a Vapor Compression Refrigeration System Using Hydrocarbon," http://dx.doi.org/10.1080/15435075.2011.621491, vol. 9, no. 7, pp. 702-717, October 2012.

[7] C. Wantha, "Analysis of heat transfer characteristics of tube-in-tube internal heat exchangers for HFO-1234yf and HFC-134a refrigeration systems," Appl. Therm. Eng., vol. 157, p. 113747, July 2019.

[8] C. Mateu-Royo, A. Mota-Babiloni, J. Navarro-Esbrí, and Á. Barragán-Cervera, "Comparative analysis of HFO-1234ze(E) and R-515B as low GWP alternatives to HFC-134a in moderately high temperature heat pumps," Int. J. Refrig., vol. 124, pp. 197-206, April 2021.

[9] Gaurav and R. Kumar, "Computational energy and exergy analysis of R134a, R1234yf, R1234ze and their 
mixtures in vapour compression system," Ain Shams Eng. J., vol. 9, no. 4, pp. 3229-3237, December 2018.

[10] R. Prabakaran, D. Mohan Lal, S. Devotta, and S. Devotta-Former Director, "Effect of thermostatic expansion valve tuning on the performance enhancement and environmental impact of a mobile air conditioning system," J. Therm. Anal. Calorim., vol. 143, pp. 335-350, 2021.

[11] J. M. Belman-Flores, V. H. Rangel-Hernández, S. Usón, and C. Rubio-Maya, "Energy and exergy analysis of R1234yf as drop-in replacement for R134a in a domestic refrigeration system," Energy, vol. 132, pp. 116-125, August 2017.

[12] R. Ben Jemaa, R. Mansouri, I. Boukholda, and A. Bellagi, "Energy and exergy investigation of R1234ze as R134a replacement in vapor compression chillers," Int. J. Hydrogen Energy, vol. 42, no. 17, pp. 1287712887, April 2017.

[13] A. Yataganbaba, A. Kilicarslan, and I. Kurtbaş, "Exergy analysis of R1234yf and R1234ze as R134a replacements in a two evaporator vapour compression refrigeration system," Int. J. Refrig., vol. 60, pp. 26-37, December 2015.

[14] J. Gill, J. Singh, O. S. Ohunakin, and D. S. Adelekan, "Exergy analysis of vapor compression refrigeration system using R450A as a replacement of R134a," J. Therm. Anal. Calorim. 2018 1362, vol. 136, no. 2, pp. 857-872, August 2018.

[15] M. H. Shaik, S. Kolla, and B. P. Katuru, "Exergy and energy analysis of low GWP refrigerants in the perspective of replacement of HFC-134a in a home refrigerator,"

https://doi.org/10.1080/01430750.2020.1730960, 2020.

[16] C. H. de Paula, W. M. Duarte, T. T. M. Rocha, R. N. de Oliveira, and A. A. T. Maia, "Optimal design and environmental, energy and exergy analysis of a vapor compression refrigeration system using R290, R1234yf, and R744 as alternatives to replace R134a," Int. J. Refrig., vol. 113, pp. 10-20, May 2020.
[17] A. Mota-Babiloni, P. Makhnatch, and R. Khodabandeh, "Recent investigations in HFCs substitution with lower GWP synthetic alternatives: Focus on energetic performance and environmental impact," Int. J. Refrig., vol. 82, pp. 288-301, October 2017.

[18] V. Pérez-García, J. M. Belman-Flores, J. L. Rodríguez-Muñoz, V. H. Rangel-Hernández, and A. Gallegos-Muñoz, "Second Law Analysis of a Mobile Air Conditioning System with Internal Heat Exchanger Using Low GWP Refrigerants," Entropy 2017, Vol. 19, Page 175, vol. 19, no. 4, p. 175, April 2017.

[19] S. Golzari, A. Kasaeian, S. Daviran, O. Mahian, S. Wongwises, and A. Z. Sahin, "Second law analysis of an automotive air conditioning system using HFO$1234 y f$, an environmentally friendly refrigerant," Int. J. Refrig., vol. 73, pp. 134-143, January 2017.

[20] E. W. Lemmon, M. L. Huber, and M. O. McLinden, "NIST Standard Reference Database 23: Reference Fluid Thermodynamic and Transport Properties-REFPROP, Version 9.1.”.

[21] H. Caliskan, "Energy, exergy, environmental, enviroeconomic, exergoenvironmental (EXEN) and exergoenviroeconomic (EXENEC) analyses of solar collectors," Renewable and Sustainable Energy Reviews, vol. 69. Elsevier Ltd, pp. 488-492, 1 March 2017.

[22] H. Caliskan, "Novel approaches to exergy and economy based enhanced environmental analyses for energy systems," Energy Convers. Manag., vol. 89, pp. 156-161, January 2015.

[23] B. Atilgan and A. Azapagic, "Assessing the Environmental Sustainability of Electricity Generation in Turkey on a Life Cycle Basis," Energies, vol. 9, no. 1, p. 31, January 2016. 